ISSN 2519-2523 (print)

Chornomors'ka mynuvshyna. - 2020. - No.15

DOI: $10.18524 / 2519-2523.2020 .15 .218673$

УДК 94(477)

\title{
ADZHIDERE / HADZHIDERE: TO THE QUESTION ON THE OTTOMAN NAME OF THE VILLAGE OF OVIDIOPOL
}

Oleksandr Sereda

ORSID: https://orcid.org/0000-0002-5921-8907

$\mathrm{PhD}$ (History), Associate Professor

South Ukrainian National Pedagogical University

named after K. D. Ushynsky

26, Staroportofrankivs'ka St., Odessa, 65020, Ukraine

olexer@ukr.net

The purpose of this article is to study the use of the Ottoman name of the modern village of Ovidiopol from the first mention of the settlement to its final renaming by the Russian government (1756 - 1794). The examples show the designation of the settlement in Ottoman-Turkish sources and the transformation of the name when translated into other languages and in particular into Russian. One of the first known written mentions of the name of Adzhidere can be found in Ottoman-Turkish sources of the middle of the XVIII century. from the Government Ottoman Archives in Istanbul. In particular, the oldest designation of the settlement on the site of the modern village of Ovidiopol is in an extract from the port log / defter, which contains information on loading and dispatching merchant ships from Adzhidere Pier to Istanbul's harbor Kapan-i Dakik - the coastal quarter in Golden Horn Bay. The annotation to this document states that the port log / defter is the register of loading and dispatch of grain from the port of Adzhidere since the beginning of the month of Muharram in 1170 AH, which corresponds to the date from September 26, 1756. In the report of the Russian intelligence of 1758 Ovidiopol is already mentioned as Gadzhidere. In particular, it is reported about the purchase of wheat and rye by Turks, Crimean Tatars, Nogai, Greeks and Wallachians, and its transportation to "different cities such as Ochakov, Belgorod and Hadzhidere, Bender, Kiliya, Smailov (Izmail) and the Wallachian city Iasi" The next source, with the designation Adzhidere, are the Ottoman-Turkish documents of the Governmental Ottoman Archive in Istanbul from the collection "State Administration", dated 1765. The documents contain several different texts from public institutions and resolutions to be implemented. A number of sources of the next period of 1780-90s indicate the Ottoman name of modern Ovidiopol both Adzhidere and Hadzhidere. Thus, in the travel description of the French engineer Lafitte-Clave, who worked for the military department of the Ottoman Empire in 1784-87, "Hadzhi Dere" was mentioned. In the description of the Ochakov land made by the Russian engineer De Volan in 1791, it is said about Adzhidere after the Russo-Turkish wars. Such double names of settlements are sometimes found in Ottoman documents due to the ignorance of the Ottoman bureaucracy of toponyms of remote regions of the Ottoman state. Such a document is the Ottoman map of 1790, as evidenced by the content of inscriptions and explanations to the settlements. A new source has been put into scientific circulation - a cartographic image of the Dniester estuary with marked key settlements on its shores and defined areas of navigation through the estuary straits with the Black Sea.

Key words: Adzhidere, Ovidiopol, Dniester Estuary, Ottoman-Turkish sources, toponymy. 
Олександр Середа

ORSID: https://orcid.org/0000-0002-5921-8907

Кандидат історичних наук, доцент

Південноукраїнський національний педагогічний

університет імені К. Д. Ушинського

Вул. Старопортофранківська, 26, м. Одеса, 65020, Україна

olexer@ukr.net

\section{АДЖИДЕРЕ / ХАДЖИДЕРЕ: ДО ПИТАННЯ ОСМАНСЬКОЇ НАЗВИ СЕЛИЩА ОВІДІОПОЛЬ}

Метою иієї статті є дослідження використання османської назви сучасного селища Овідіополь від першої згадки населеного пункту до остаточного перейменування його російським урядом (1756 - 1794). На прикладах надано позначення населеного пункту в османсько-турецьких джерелах $i$ трансформація назви при перекладах на інші мови $i$ зокрема на російську. Введено у науковий обіг нового джерела - картографічного зображення Дністровського лиману з позначеними ключовими населеними пунктами на його берегах та визначеними сферами судноплавства протоками лиману з Чорним морем.

Ключові слова: Аджидере, Овідіополь, Дністровський лиман, османсько-турецькі джерела, топонімія.

Османське панування у Північно-Західному Причорномор'ї позначилось розбудовою здавна існуючих міст-фортець Аккерман, Кілія, Очаків, Бендер i Ходжабей. Окрім цього, залюднення степових просторів Очаківської землі на межі XVII - XVIII ст. спонукає до будівництва нових портів чи пристань для логістичного забезпечення темпів зростаючого зернового виробництва на причорноморських степах. У такому вирішенні питання османська влада навпроти Аккермана будує на лівому березі Дністровського лиману нову хлібну гавань, яка має за різними письмовими i картографічними джерелами назву Аджидере чи Хаджидере (у російській абревіатурі Гаджидере).

Визначаючи перешоджерела назви населеного пункту передусім потрібно звернути увагу на документи інформаційно-просторового поля османської бюрократії, в межах якого найбільше зустрічається османсько-турецьке позначення назви селища. Одними 3 перших відомих письмових позначень Аджидере є декілька османськотурецьких джерел середини XVIII ст. $з$ Урядового Османського Архіву у Стамбулі. Зокрема, найбільш давнім позначенням населеного пункту на місці сучасного селища Овідіополь $є$ виписка 3 портового журналу/дефтеру, в якому міститься інформація про завантаження i відправки торговельних суден 3 пристані Аджидере до стамбульської гавані Капан-и дакік [1] - прибережного кварталу в затоці Золотого Рогу Стамбула. В анотації до цього документа зазначено, що портовий журнал/дефтер $\epsilon$ регістром завантаження і відправлення збіжжя 3 пристані Аджидере 3 початку місяця мухаррем 1170 р. за хіджрою, що відповідає терміну з 26 вересня 1756 р. В самому дефтері відображено реєстраційні дати прибуття суден 3 вересня по листопад 1756 р., до часу замерзання прісноводного лиману Дністра.

Відповідно до записів дефтеру, для відправки до Стамбула двох основних продуктів - пшениці й ячменю, в Аджидере завантажено на 23 судна, з яких більшість мали фрахтування у стамбульській гавані Капан-и дакік та Аккермані, а решта з портів Варна, Трабзон та Уньє. Загальна кількість завантажень відправленого збіжжя у дефтері становила вагу 20773 аккерманських кілє, що відповідало 70850 стамбульським кілє 
(приблизно 1771,25 т. зерна). У документі також зазначено відвантаження у цей самий період 1756 р. з Аккермана - 57150 стамбульських кілє пшениці та ячменю, що на чверть менше від Аджидере. У той же час зазначається, що Аджидере знаходиться у судовоадміністративному окрузі “каза Аккерман” [8, с. 210-214].

Подальше зазначення Овідіополя саме за назвою Аджидере також відображено в наказі кримського хана, датованого груднем 1758 р., щодо постачання зернового збіжжя до Стамбула, де Аджидере фігурує як основний порт/пристань у якості пункту збору зернових з Очаківської землі загалом і зокрема з Ханської України [2; 5, с. 188]. Однак в донесенні російської розвідки цього ж 1758 р. Овідіополь зазначається вже як Гаджидере. Зокрема, повідомляється щодо закупівлі турками, кримськими татарами, ногайцями, греками і волохами пшениці і жита та його звезення до «міст різних як-то до Очакова, Білгорода й Гаджидери, до Бендер, Кілії, Смаілова (Ізмаїл) і до волоського міста Яси» [6, с. 64-65].

Наступним джерелом, 3 позначенням Аджидере є османсько-турецькі документи Урядового Османського Архіву у Стамбулі 3 колекції «Державна адміністрація», датовані 1765 р. Документи містять декілька різних текстів з інституцій державного управління і резолюцій до виконання. Всі тексти інформують про повідомлення голови адміністрації Ходжабею - Хафиз Ельхадж Мехмеда до Очаківського валії/губернатора, Аккерманського кадія/судді і до командира яничарського корпусу; листом кримського хана; документами канцелярії великого везіра та іншими відомчими вписуваннями щодо неправомірних дій перекупників зерна з Аджидере [3] i спекуляції у розрахунках з ногайцями Єдисанської орди, що було виявлено під час інспекції зернових складів у селищі Аджидере кримським володарем Селім Герей ханом. Зокрема, наголошувалось на утисках представників «Єдисанської орди, які їуть з місияь відстанню 20-30 годин шляху $і$ які привозили пшеницю, ячмінь, свіже молоко $і$ оброблені шкіри». Як вирішення цієї проблеми наказувалось «... від ияього часу і на майбутнє, все привезене з Сдисанської орди масло, пшениця і ячмінь, нехай не направляють до пристані Аджидере $i$ не продають торговиям, а всі згадувані продукти нехай довозять до пристані Ходжабей, щзоби відправити до столиці» [1].

Низка джерел наступного періоду 1780-90-х років позначають османську назву сучасного Овідіополя як і Аджидере, так і Гаджидере. Так у подорожньому описі французького інженера Лафитте-Клаве, який працював на військове відомство Османської імперії у 1784-87 роках зазначалось: «Гаджи-Дере, розташовано на іншій стороні ріки навпроти Аккермана, в затоиі чи западині ї̈ лівого берега, де його перетинає струмок, від якого селище отримало свою назву. Як розказують, воно було більше ніж Аккерман, але зруйновано росіянами під час минулої війни [1768-1774р.] $i$ не відновлено до попереднього стану» [9, с. 82].

Натомість в описі Очаківської землі здійсненого російським інженером ДеВоланом у 1791 році, говориться про Аджидере по закінченню російсько-турецьких війн, зазначаючи що: «положення Аджидері, вочевидь, було дуже привабливим під час його розквіту. ... Руїни, які засвідчують існування изього міста, мають близько трьох з половиною верст у периметрі. ... Молдовани, які мешкають в Калаглеї у 5 вестах звідси, говорять про Аджидері як про земний рай і особливо хвалять вино, яке тут робили, вважаючи його кращчим в усій Молдові та Бессарабії. ... Аджидері [до війни 1787-1791 р.] був найбільшим містом иієї провіниії після Очакова та мав, скоріш за все, досить значний ринок вивезення пшениці і худоби (переважно баранів) до Константинополя» [10, с. 99-100]. 
Принаймні до 1794 року російська адміністрація продовжує називати Овідіополь османською назвою Аджидере. Зокрема у дозвільних документах архіву Очаківської портової митниці щодо торговельної діяльності окремих купців, міститься справа «очаківського купця Георгія Врета, який вирішував питання безперешкодної доставки пшениці до Очакова від Аджидера для відправлення до Константинополя (1794р.)» [7].

Таке чергування назви Аджидере з Хаджидере/Гаджидере $\epsilon$ притаманним в османських найменуваннях при перекладі на інші мови. Таке ж чергування часто зустрічається в османській назві міста Одеса. Якщо більш давня назва Одеси у XVI ст. позначалась як Коджабей, то в XVII ст. частіше використовується Ходжабей. Однак у XVIII ст. наряду з назвою Ходжабей все частіше в кириличних і латиничних джерелах зустрічається найменування Хаджибей, Гаджибей чи Аджибей. Якщо для нетюркського джерела таке позначення є особливостями латинської і кириличної вокалізації османської назви Ходжабей, то при тюркському написанні назви Хаджибей, Гаджибей чи Аджибей отримуємо зовсім інше інформаційно-змістовне поняття при перекладі. Так само i османська назва Аджидере у порівнянні 3 Хаджидере / Гаджидере має різний зміст. «Аджи-дере» - буквально перекладається як «Гірка долина», натомість «Хаджи-дере / Гаджи-дере» у перекладі означає «Долина паломника».

Такі подвійні назви населених пунктів подеколи зустрічаються і в османських документах через незнання османською бюрократією топонімів віддалених регіонів Османської держави. Таким документом є османська карта 1790-го р. [4], про що свідчить зміст надписів і пояснень до населених пунктів. Зокрема на місці сучасного Овідіополя міститься напис:

«Розпочате здійснення будівництва фортеці в Хаджидере»

[Hacıdere'de inşâya mübâş̧eret eyledükleri kal'a]

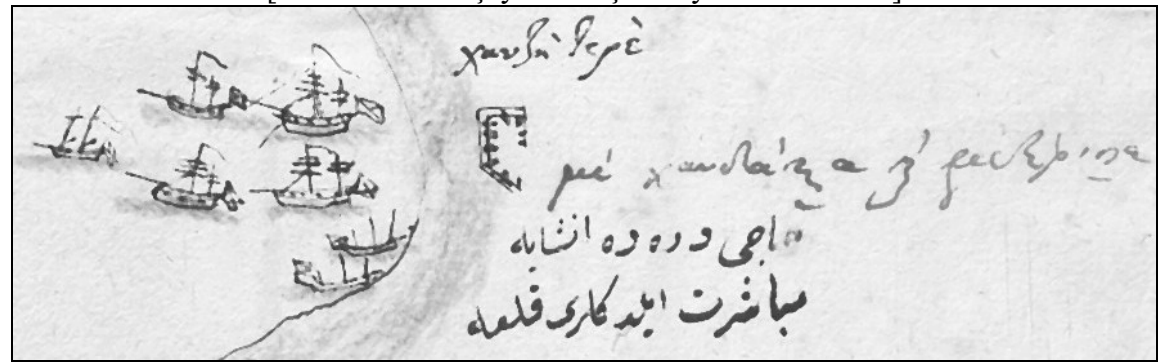

Початок будівництва фортеці в Аджидере розпочинається у 1790 р., тому саме за цим роком можна датувати османську карту, в архівній анотації до якої зазначається похибка дати на п'ятдесят років пізніше. Ще одним аргументом до датування карти саме 1790 р. є позначення незвичним чином проливів з Дністровського лиману до Чорного моря. Традиційно відоме Царгородське чи Стамбульське гирло позначено як Мусульманська протока. Натомість Очаківське гирло представлене як Московська протока. Отже, на карті зазначались сфери судноплавства, закріплені за османським (мусульманським) і російським (московським) флотами. До того ж, османська назва «Аджидере» на карті означена за російською вокалізацією «Гаджидере».

Натомість у центральному надпису на картографічному зображенні Дністровського лиману міститься надпис-пояснення відстані до Аккермана 3 притаманним османським написанням «Аджидере»: 
«3 Аккермана до фортеці Аджидере напряму є відстань у чотири - п’ять миль» [Akkerman'dan Acıdere kal'asına dek dört - beş mil mesafe vardır]

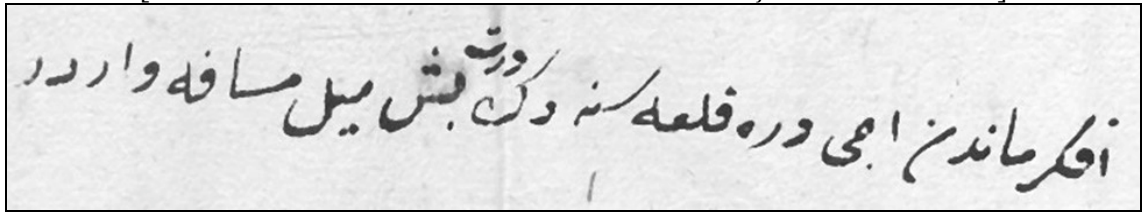

Отже, можна стверджувати щодо вживання османської назви Овідіополя Аджидере протягом другої половини XVIII ст. передусім в османських документах, а також назви Хаджидере чи Гаджидере як в османських, так і в інших джерелах. Принаймні з першої згадки в османських офіційних реєстрах від 26 вересня 1756 р. до часу повідомлення Очаковської митниці у 1794 р. існує історична тяглість, безперервність у вживанні назви населеного пункту як Аджидере.

\section{Карта глибин Дністровського лиману і протоків}

Додатки:

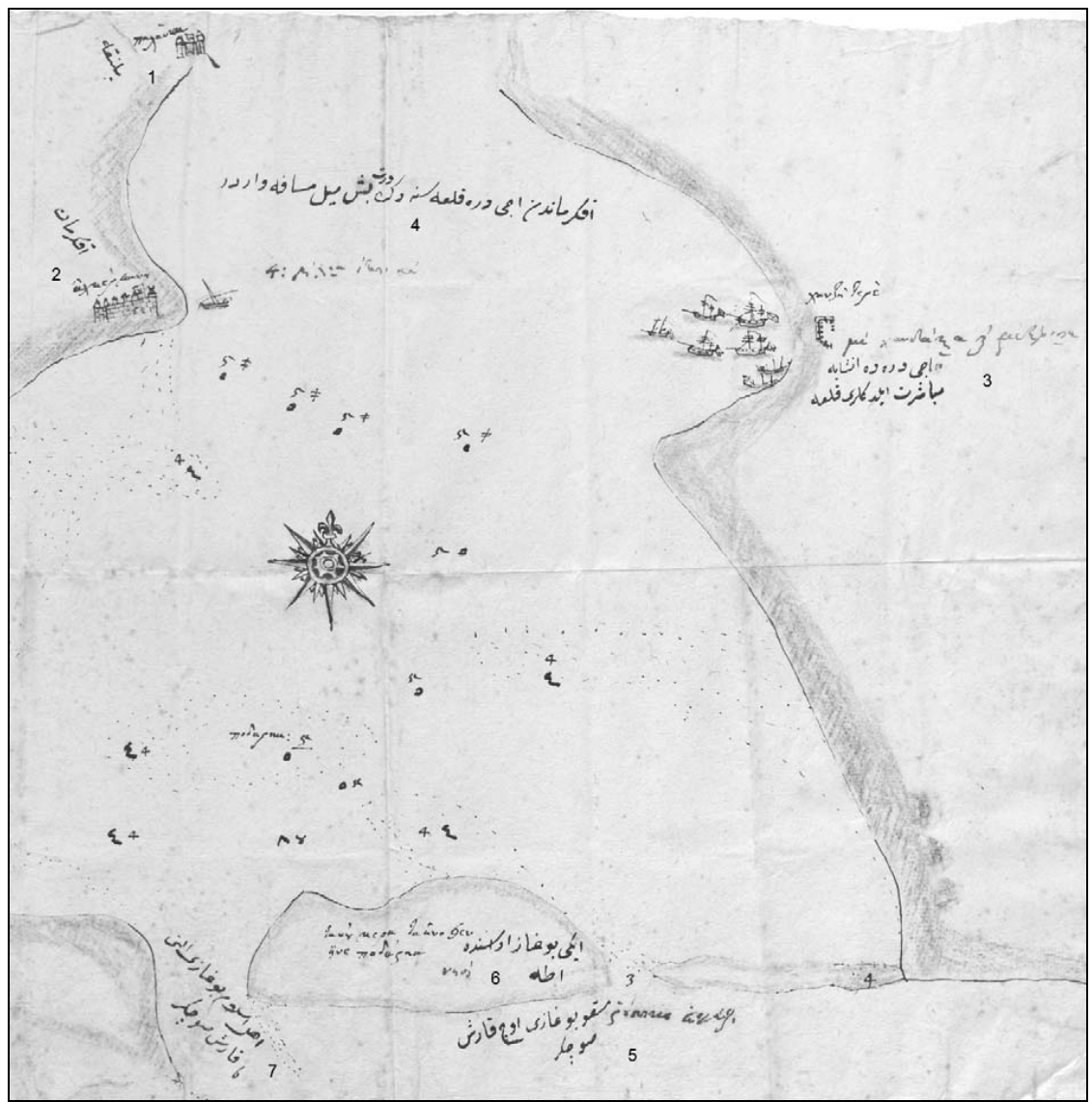


1 [Palanka] Паланка

2 [Akkerman] Аккерман

3 [Hacıdere'de inşâya mübâşeret eyledükleri kal'a]

Розпочате здійснення будівництва фортеці в Хаджидере

4 [Akkerman'dan Acıdere kal'asına dek dört - beş mil mesafe vardır]

3 Аккерману до фортеці Аджидере напряму є відстань у чотири - п'ять миль

5 [Moskov boğazı üç karış su çeker]

Московська протока глибиною на три ліктя

6 [iki boğaz arasında ada]

острів поміж двома проливами

7 [Ehl-i İslam boğazı altı karış su çeker]

Мусульманська протока глибиною на шість ліктів

Джерела та література:

1.Başbakanlık Osmanlı Arşivi (далі BOA). - Fon adı: “C.BDL.”. - Dosya № 38. Gömlek № 1865. [1178 Ş $21 / 13.02 .1765]$

2.BOA. Fon ad1: "C.HR." Gömlek № 1087. [1172 R 21 / 22.12.1758]

3.BOA. Fon adı: “D.MKF.d.”. Defter № 29796-Y. [1170 sene / 26.09.1756-14.09.1757]

4.BOA. Fon adı: "HAT.”. Dosya № 1387, Gömlek № 55149. [1768 - 1791].

5.Osmanlı belgelerinde Kırım Hanlı̆ 1 $=$ [Crimean Khanate in Ottoman documents]. İstanbul. 2013.

6.Аргатюк С. С. Аджидер-Овидиополь: очерки по археологии и истории города и крепости. /

С. С. Аргатюк, В. В. Левчук, И. В. Сапожников. - Одеса-Овидиополь, 2015. - С. 64-65.

7.Головко Ю. І. Матеріали фонду Очаківської портової митниці Державного архіву Миколаївської області як джерело 3 історії зовнішньої торгівлі Південної України кінця XVIII - початку XIX ст. / Ю. І. Головко // Історія торгівлі, податків та мита: збірник наукових праць. - 2012. - № 1. - С.60-67.

8.Середа О. Османсько-українське степове порубіжжя в османсько-турецьких джерелах XVIII ст. / О. Середа. - Одеса, 2015. - С. 210-214.

9. [Лафитте-Клаве] Описание пути от Константинополя до Очакова / [Лафитте-Клаве]. СПб., 1821.

10. Отчет относительно географического и топографического положения провинции Озу или Едисан, обычно называемой Очаковская степь, служащий пояснением к картам и планам, снятым по высочайшему указанию. 1792 г. // Наследие Ф. П. Де-Волана. Из истории порта, города, края. -Одесса. - 2002. - С. 99-100.

\section{References:}

1. Başbakanlık Osmanlı Arşivi (afterwards: BOA). Fon adı: "C.BDL.”. Dosya № 38. Gömlek № 1865. [1178 \$̧ $21 / 13.02 .1765]$.

2. BOA. Fon adı: "C.HR." Gömlek № 1087. [1172 R 21 / 22.12.1758]

3. BOA. Fon ad1: "D.MKF.d.". Defter № 29796-Y. [1170 sene / 26.09.1756-14.09.1757]

4. BOA. Fon adı: "HAT.”. Dosya № 1387, Gömlek № 55149. [1768 - 1791].

5. Osmanlı belgelerinde Kırım Hanlığ $=$ [Crimean Khanate in Ottoman documents], 2013. İstanbul. [in Turkish]

6. Argatiuk, S. S., Levchuk, V. V., Sapozhnikov, I. V., 2015. Adzhider-Ovidiopol: ocherki po arheologii i istorii goroda i kreposti. Odesa-Ovidiopol. [in Ukrainian]

7. Golovko, Yu. I., 2012. Materialy fondu Ochakivskoi portovoi mytnytsi Derzhavnogo arhivu Mykolaivskoi oblasti yak dzherelo z istorii zovnishnioi torgivli Pivdennoi Ukrainy kintsia XVIII pochatku XIX st. Istoria torgivli, podatkiv, ta myta: zbirnyk naukovyh prats, 1. [in Ukrainian]

8. Sereda, O., 2015. Osmansko Ukrainske stepove porubizhzhia v osmansko-turetskih dzherelah XVIII st. Odesa. [in Ukrainian] 
9. [Lafitte-Klave], 1821. Opisaniye puti ot Konstantinopolya do Ochakova. Sankt-Peterburg. [in Russian].

10. Otchet otnositel'no geograficheskogo i topograficheskogo polozheniya provintsii Ozu ili Edisan, obychno nazyvayemoy Ochakovskaya step', sluzhashchiy poyasneniyem k kartam i planam, snyatym po vysochayshemu ukazaniyu. 1792 g. In: Naslediye, F. P., 2002. De-Volana. Iz istorii porta, goroda, kraya. Odessa. pp. 99-100. [in Russian].

Отримано: 02.12.2020 p. 